\title{
M-BANKING: PERSPECTIVE IN INDIAN BUSINESS
}

\author{
Naib Singh ${ }^{1 *}$ \\ *11M. Phil., M.Com. UGC-NET Assistant Professor, Deptt. of Commerce, Rajiv Gandhi Govt. College, \\ Saha Cell: 9467470010
}

*Corresponding Author: -

\begin{abstract}
: -
Mobile banking in India is gaining more and more popularity in the present scenario. India is occupying the position of second largest mobile market in the world after China. The major finding of the study is that the future of mobile banking in India will be bright and certainly be more helpful in the development of banking sector. Our country is having vast access of mobile phone services as compared to developed European countries. In the year 201322.51 million people were using these services. The objective of the anytime banking can easily be obtained by mobile banking.
\end{abstract}

Keywords: - M-Banking. Mobile Market. TRAI. USSD. Mobile Banking Users. 


\section{INTRODUCTION}

M-Banking refers to mobile banking. In the present world of innovative business, a business can survive if it prefers to use latest technology. Modern age is using information technology more than the use of other technologies. Mobile phones are the means for using new and advanced technological features. Maximum research is taking place in the mobile Industry for making the people more advanced for controlling the life by using just a click. At the end of 2013, 21.61 million people were using narrow and broadband internet connections in the country.

Banking can be expressed in to two meaning, one concept is of traditional banking which is accepting and safeguarding the public money and lending out it for making profit. Another concept is modern banking which includes debit cards, credit cards, ATM facilities, CDM facilities, on-line payments, fund transfers and lockers facilities. When all these functions and transactions are performed with the mobile phone then this practice is termed as mobile banking.

People use mobile banking due to easy access of the bank in their hands. They do not have to go bank, they can check their account balance, they can easily operate mobile phone generally that the use of computer. Due to these benefits, the mobile banking is gaining more popularity these days. Mobile banking transactions are cheaper that other ways of banking.

\section{Research Design}

Present study is a general study of banking transactions by the use of mobile phones. This is not any particular study hence cannot be applied to any specified segment of the banking or mobile sector. Data are used in the study from secondary sources from the reports of various organizations and internet sites. Findings have been extracted on the basis of study in the end of the paper.

\section{Objective of the study}

The study is focusing on the role of mobiles phones in the banking transactions in India. The purpose of the discussion is to identify the present scenario of mobile banking and an attempt has been made to point out the best use of mobile banking in the coming years.

\section{Present Scenario}

India is occupying the position of second largest mobile market in the world after China. Our country is having vast access of mobile phone services as compared to developed European countries. This trend depicts that the future of the use of mobile phones in the banking transactions in India is having great potential. Ninety seven banks of public and private sector have been permitted to provide mobile banking services by the reserve bank of India. Reserve Bank of India has given the directions to banks under section 18 of Payment \& Settlement Systems Act, 2007 to provide the mobile banking facilities smoothly.

Table 1: Mobile Banking Users in India (In Millions)

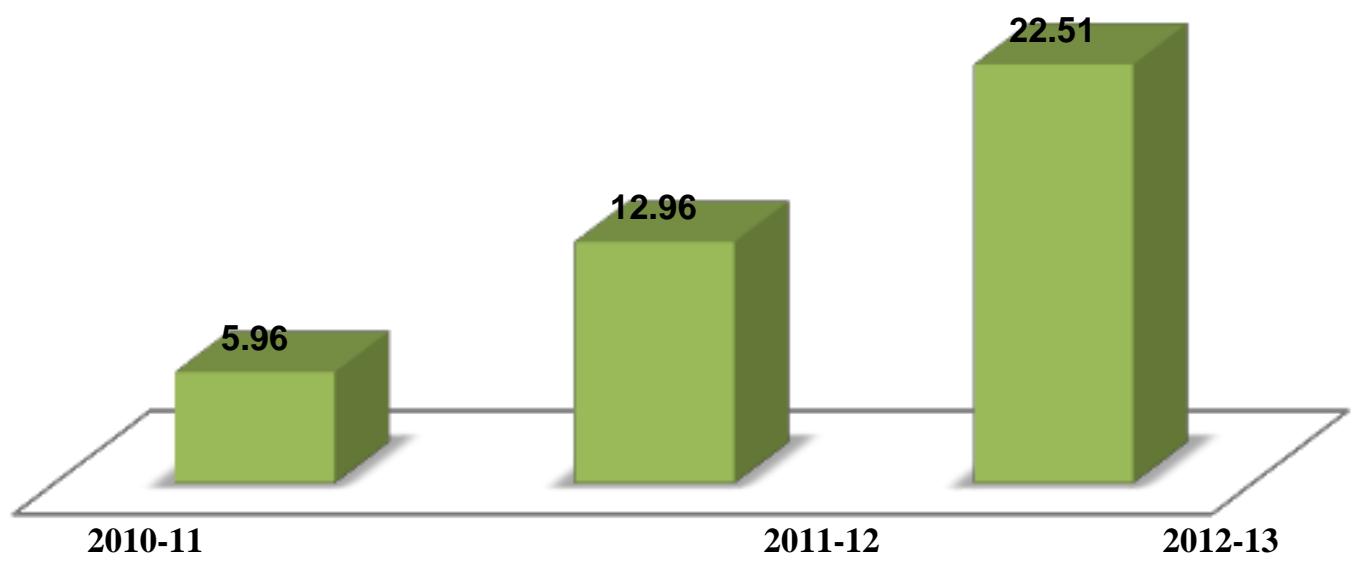

Source: Report of the Technical Committee, Reserve Bank of India, January 2014.

In 2010-11 only 5.96 million people were using mobile banking services in the country but within three years this strength has increased near to five times. In the year 201322.51 million people were using these services. A new service in the area of mobile banking is to knock the door these days is Unstructured Supplementary Service Data (USSD) Scheme in which the customers can easily use their phones to maintain their banking transactions. It is very simple text messaging system for handling the online payments; balances checking, swiping, fund transfers, debiting and crediting. Under this facility a subscriber will not require any type of internet connection or even a smart phone. The concept of anytime and anywhere banking will be more popular in the future and mobile banking is the best way for grabbing this type of business sector. 
The Mobile Banking (Quality of Service) Regulations, 2012

TRAI has framed this Act to provide mobile banking to the larger part of the population in the smooth manner. Provisions have been framed to provide the facilities of USSD, SMS more fastly and conveniently. Mobile companies will have to follow the TRAI standard related to internet services. This Act empowers the TRAI to take indisciplinary action against the mobile companies in case of not following requirements and guidelines under the rules.

\section{Findings}

At present 220 million people are using mobile internet in India and this figure is likely to grow upto 500 million in next three to four years. Telecom industry is going to catch four generation era which certainly increase the mobile network coverage. Reserve Bank of India is making efforts frequently for streamlining the mobile banking in the country. Thus, in coming years mobile banking will certainly grow at the fast beat. For achieving better results mobile companies should ensure easy access of the mobile banking facilities to more and more subscribers. Mobile banking will be helpful for the banks for attaining their goal of financial inclusion and bringing down the transaction costs.

\section{References}

[1].Tomar Dinesh (2010), Theory of Banking: History, Law and Practice, Vista International Publishing house, Delhi.

[2].Datt Ruddar Sundharam K.P.M. (2007), Indian Economy, S. Chand and Company Ltd., New Delhi. Das Debabrata (2010): "Banking Revolution", Frontline, December, No 24, Vol 27, pp120-122.

[3].Sangeeta (2013): "Emerging Trends in banking Challenges and Opportunities", Research Link- An International Journal-113, august, Vol-XII (6), pp 118.

[4].Mohan Ram T T (2008): "reforming the Banking sector", Economic \& Political Weekly, August, No 32, Vol XLIII, pp 28.

[5].Cellular Operators Association of India's Report: Moving up the I-Way, Annual Report 2013-14. Annual Report of Telecom Regulatory Authority of India, 2012-13.

[6].Report of the Technical Committee, Reserve Bank of India, January 2014. The Mobile Banking (Quality of Service) Regulations, 2012 http://economictimes.indiatimes.com http://www.allbankingsolutions.com

[7].http://ptlb.in http://www.psalegal.com rbi.org.in 